Jurnal PG-PAUD Trunojoyo : Jurnal Pendidikan dan Pembelajaran Anak Usia Dini, Volume 7, Nomor 2, Oktober 2020 hal 44 - 51 , ISSN : 2528-3553 (online), ISSN: 2407-4454 (print)

\title{
PENGEMBANGAN KEMAMPUAN BEKERJASAMA ANAK MELALUI PERMAINAN KREATIF POHON DAN TUPAI
}

\author{
Putri Purnama Sari ${ }^{1}$ \\ Hanggara Budi Utomo ${ }^{2}$ \\ Rosa Imani Khan ${ }^{3}$ \\ ${ }^{1,2,3}$ PG-PAUD Universitas Nusantara PGRI Kediri \\ Email:sariputri96593@gmail.com,hanggara@unpkediri.ac.id,rossa_rose@ymail.com \\ Received (Juni), Accepted (September), Published (Oktober)
}

\begin{abstract}
Building the ability to work together in early childhood through creative games of trees and squirrels. The attitude of cooperation between friends in early childhood is an attitude of socialemotional manifestation which is essential in children's self-development. Creative games can be an alternative fun game that can improve children's collaboration skills. The purpose of this study was to explore and describe the formation of early childhood collaboration skills through creative games of trees and squirrels at TK Kusuma Mulia I Cerme, Kediri Regency. The research respondents were two people, namely the principal and one teacher. The research approach used is descriptive-analytical. The process of collecting and extracting data uses the method of observation, interviews, and uses documentation studies. The results showed that the formation of early childhood cooperative attitudes in TK Kusuma Mulia I Cerme, Kediri Regency can be done through tree and squirrel games as creative games. The role of the teacher can be manifested as a facilitator and provocateur who positively pays attention to children in order to bring out leadership in the group, and then the children are able to work together in playing trees and squirrels.
\end{abstract}

Keywords: teacher's, cooperative, early childhood, creative games with trees and squirrels.

Abstrak: Pembentukan kemampuan bekerjasama anak usia dini melalui permainan kreatif pohon dan tupai. Sikap kerjasama antar teman pada anak usia dini merupakan sikap dari perwujudan sosial emosional yang esensial dalam perkembangan diri anak. Permainan kreatif dapat menjadi salah satu alternatif permainan menyenangkan yang dapat meningkatkan kemampuan kerjasama anak. Tujuan dari penelitian ini untuk mengeksplorasi dan mendeskripsikan pembentukan kemampuan bekerjasama anak usia dini melalui permainan kreatif pohon dan tupai di TK Kusuma Mulia I Cerme Kabupaten Kediri. Responden penelitian sebanyak dua orang, yaitu kepala sekolah dan satu orang guru. Pendekatan penelitian yang digunakan adalah deskriptif analitis. Proses pengumpulan dan penggalian data menggunakan metode observasi, wawancara, dan menggunakan studi dokumentasi. Hasil penelitian menunjukkan dalam pembentukan sikap kerjasama anak usia dini di TK Kusuma Mulia I Cerme Kabupaten Kediri dapat dilakukan melalui permainan pohon dan tupai sebagai permainan kreatif. Peran guru dapat dimanifestasikan sebagai fasilitator dan provokator yang secara positif memberikan perhatian kepada anak agar memunculkan sifat kepeminpinan dalam kelompok, dan selanjutnya anak mampu bekerjasama dalam bermain pohon dan tupai.

Kata kunci: guru, bekerjasama, anak usia dini, permainan kreatif pohon dan tupai 
Jurnal PG-PAUD Trunojoyo : Jurnal Pendidikan dan Pembelajaran Anak Usia Dini, Volume 7, Nomor 2, Oktober 2020 hal 44 - 51 , ISSN : 2528-3553 (online), ISSN: 2407-4454 (print)

\section{PENDAHULUAN}

Pengembangan kemampuan sosial emosional memegang peranan penting dalam menentukan kesuksesan anak di masa depan. Kesuksesan tersebut dapat terjadi bila ada pencapaian perkembangan sosial emosional anak, seperti halnya: sikap toleran; mengekspresikan emosi senang, sedih maupun antusias; memahami aturan dan mengenali sikap sopan santun sesuai dengan norma yang ada di lingkungan masyarakat; disiplin; mampu berempati; memiliki sikap gigih; menunjukkan kebanggan atas karya sendiri; dan menghargai kelebihan orang lain, serta dapat bersikap kooperatif dengan teman.

Perkembangan sosial dan emosional merupakan dua aspek perkembangan yang berbeda, namun saling mempengaruhi. Penerapan perilaku sosial dan emosional yang dapat dilakukan anak usia dini adalah perilaku yang baik, jujur, disiplin, kemandirian, tanggung jawab, percaya diri, adil, setia kawan, sifat kasih sayang terhadap sesama dan memiliki toleransi yang tinggi (Nugraha \& Rachmawati, 2015). Ketercapaian perkembangan sosial emosional anak dapat ditinjau dari beberapa kriteria, diantaranya adalah sikap kasih sayang, partisipatif, komunikatif dan interaktif, adaptif, percaya diri, punya rasa ingin tahu yang tinggi, serta menampilkan emosi sesuai situasi dan keadaan yang dialami (Tusyana, Trengginas, \& Suyadi, 2019).

Senada dengan hal tersebut, sosialisasi dengan teman-teman sebaya penting untuk dilakukan (Kusumastuti, 2017). Sosialisasi memiliki peran penting agar kemampuan sosial yang dimanifestasikan dalam bentuk komunikasi, menunjukkan perhatian, merasakan apa yang orang lain rasakan, kesediaan berbagi, dan saling bekerjasama dapat terjalin, dengan harapan adanya penyesuaian diri pada anak, baik di lingkungan keluarga, lingkungan bermain, dan sekolah.
Perkembangan sosial dan emosional pada anak tidak dapat muncul dengan sendirinya, melainkan membutuhkan peran orang dewasa sebagai pendidik untuk menstimulasi kecakapan sosial anak sejak dini. Stimulasi kecakapan sosial ini mendorong pentingnya pengembangan sosial emosional anak, antara lain: adanya kehidupan anak yang mendasar; optimalisasi kesadaran anak; strategi pendidikan dan pengembangan anak; anak tidak dapat hidup dengan kecerdasan intelektualnya saja, tetapi juga perlu adanya kecerdasan emosional sebagai bekal kehidupan; dan tuntutan supaya anak dapat meregulasi emosi sosialnya (Nugraha \& Rachmawati, 2015)

Kemampuan kerjasama diyakini sebagai salah satu kemampuan sosial emosional yang penting untuk dikembangkan dalam diri anak. Kemampuan ini relatif masih terbatas dan masih sangat dibutuhkan oleh setiap anak. Kajian yang dilakukan Hidayati (2014) menyatakan bahwa kemampuan kerjasama atau biasa disebut sikap kooperatif dimanifestasikan untuk membentuk kebiasaan berteman yang baik sejak dini. Senada dengan hal tersebut, Kusumastuti (2017) menyatakan bahwa ketika anak sudah mengembangankan kemampuan kerjasama, maka anak sudah dapat mengembangkan kemampuan resiliensinya pada kelompok atau lingkungan tempat anak bermain. Namun demikian, jika anak tidak dapat mengembangkan emampuan kerjasama, maka anak tersebut akan tersingkir dan terkucilkan dari pergaulannya. Anak yang dikucilkan cenderung agresif, berperilaku anti sosial, sulit bekerjasama, egois, dan cenderung mengganggu kesenangan anak lain (Safaria, 2005).

Kondisi ideal mengenai kemampuan kerjasama pada anak tersebut terindikasi berbeda dengan fakta mengenai berbagai karakteristik anak usia dini. Berdasarkan data penelitian yang dilaporkan Kusumatuti (2017) bahwa sebesar 40 persen kemampuan kerjasama anak dalam kategori kurang baik, 
Jurnal PG-PAUD Trunojoyo : Jurnal Pendidikan dan Pembelajaran Anak Usia Dini, Volume 7, Nomor 2, Oktober 2020 hal 44 - 51 , ISSN : 2528-3553 (online), ISSN: 2407-4454 (print)

dan sebesar 20 persen anak tidak dapat mengembangakan kemampuan kerjasama dengan temannya. Senada dengan hal tersebut, Hidayati (2014) melaporkan bahwa perilaku anak masih belum berkembang untuk dapat bekerja dalam kelompok, masih enggan bermain bersama-sama, dan kurang menunjukkan sikap kepedulian terhadap teman. Fakta lainnya, seperti yang disampaikan Fauziddin (2016) menunjukkan bahwa sikap kerjasama yang dilakukan anak kelompok A di TK Kartika Salo menunjukkan kurang optimal dalam berinteraksi dengan teman sebesar 44\%, dan aspek tanggung jawab yang masih kurang optimal dengan prosentase sebesar 38,8\%.

Hasil pengamatan dan wawancara yang dilakukan oleh peneliti saat pembelajaran pada anak usia 5-6 tahun di TK Kusuma Mulia I menunjukkan bahwa sebagian besar anak mengalami kesulitan dalam bersosialisasi dan bekerjasama dalam sebuah kegiatan, sehingga dapat menimbulkan kemampuan bekerjasama anak kurang berkembang optimal. Hal ini terlihat pada kurangnya interaksi antar anak, anak masih enggan untuk bermain bersama-sama, serta anak masih menonjolkan keegoisannya, yang tampak pada sikap tidak perduli terhadap teman. Hasil observasi tersebut mengasumsikan bahwa anak-anak di TK Kusuma Mulia I Cerme, khususnya anak usia 5-6 tahun terindikasi masih kesulitan dalam bekerjasama. Hasil wawancara peneliti dengan guru, diperoleh bahwa masih ada anggapan guru terhadap anak yang belum mampu untuk saling berbagi dan terlibat dalam kegiatan bermain. Peran guru di TK Kusuma Mulia I selama ini yang dilakukan tertuju pada kegiatan bercerita dan ceramah pada semua aspek pengembangan, dan belum mengaplikasikan praktek langsung kepada anak dalam melakukan kerjasama.

Kemampuan kerjasama bila tidak dikembangkan dengan baik, maka akan berdampak kurang baik pada proses ketika anak melakukan penyesuaian diri, baik pada penyesuaian akademik maupun penyesuaian sosial anak (Hidayati, 2014). Oleh karena itu berdasar uraian di atas, peneliti perlu mengatasi permasalahan tersebut sehingga ada peningkatan kemampuan kerjasama anak. Peningkatan kerjasama anak dapat dilakukan dengan upaya melalui kegiatan bermain. Kegiatan bermain dapat dirasakan oleh anak ketika anak mengalami kegiatan tersebut secara langsung. Manfaat bermain untuk pengembangan kerjasama menurut Tedjasaputra (2001), antara lain: (1) berkembang kemampuan fisik anak karena melibatkan gerakan tubuh sehingga membuat tubuh anak menjadi sehat, dan sisi yang lain anak dapat menyalurkan tenaga yang berlebihan sehingga anak tidak merasa gelisah bosan dan tertekan; (2) berkembang kemampuan sosial, dimana ketika anak bermain, anak akan belajar tentang aturan yang sudah dibuat, kebiasaan-kebiasaan bermain sesuai budaya yang ada; (3) berkembang kemampuan emosi atau kepribadian pad aaktivitas bermain yang dilakukan. Anak dapat merasa enjoy sekaligus adanya pemenuhan kebutuhan dasar yang membentuk motivasi anak, serta membentuk kepercayaan diri yang positif; (4) berkembang kemampuan kognisi, bahwa melalui bermain anak mempelajari sesuatu yang baru sebagai dasar untuk pengembangan membaca, menulis, dan berhitung, serta pengetahuan lain yang terkait.

Secara mendasar, Mutiah (2010) menyatakan bahwa ketika anak-anak belajar melalui permainan dan kegiatan bermain, maka akan tumbuh dan berkembang pada diri anak aspek perkembangan yang ada pada dirinya baik fisik, intelektual, bahasa dan perilakunya. Salah satu tahap perkembangan bermain sosial anak adalah permainan kerjasama (cooperative play). Tedjasaputra (2001) menjelaskan bahwa ada peningkatan prosentase pada tahapan bermain kooperatif yaitu sebesar 6 persen dari anak usia 3-4 
Jurnal PG-PAUD Trunojoyo : Jurnal Pendidikan dan Pembelajaran Anak Usia Dini, Volume 7, Nomor 2, Oktober 2020 hal 44 - 51 , ISSN : 2528-3553 (online), ISSN: 2407-4454 (print)

tahun meningkat pada usia 5 tahun. Hal ini berarti bahwa ketika anak berusia 5 tahun, anak tersebut sudah mampu mengenali bentuk interaksi sosial dalam bentuk kerjasama, yang dimanifestasikan dalam bentuk bermain. Ismail (2006) menyatakan bahwa suasana bermain yang menyenangkan dapat berakbibat positif pada anak, diantaranya: kemampuan mengenal anak yang lebih baik, kemampuan anak untuk saling menghargai, dan dapat memunculkan kebersamaan sosial. Suasana bermain yang menyenangkan dapat diwujudkan dalam bentuk permainan kreatif. Beragam bentuk permainan kreatif yang dapat memunculkan kerjasama anak antara lain: permainan lempar tangkap bola, permainan kucing dan tikus, dan permainan ukulele (Nugraha, 2013)

Pengembangan permainan kreatif yang dapat dimodifikasi dari salah satu permainan tradisional kucing dan tikus, yaitu permainan pohon dan tupai (Nugraha, 2013; Mulyani, 2016). Permainan ini diperankan oleh anak yang telah dibagi yaitu ada yang menjadi pohon dan ada yang menjadi tupai. Permainan ini dilakukan di luar kelas atau dihalaman sekolah, dan dilakukan oleh beberapa orang anak minimal dimainkan oleh 10 anak. Permainan ini harus dilakukan dengan jumlah anak yang genap tidak boleh ganjil. Permainan pohon dan tupai dalam bentuk olahraga dapat mengembangkan fisik anak, dan dapat mendorong kemampuan sosialisasi anak. Hal ini senada dengan pendapat Nugraha (2013) bahwa ada kemauan dari diri anak untuk belajar, bersosialisasi, bekerja sama, memainkan peran pemimpin, serta anak dapat menilai diri secara realistik dalam bentuk bermain dan permainan, khususnya permainan kreatif.

Memahami akan pentingnya sikap kerjasama antar anak usia dini, maka perlu adanya pemahaman guru terhadap elemen dasar yang menjadi penciri bagaimana anak dapat bekerjasama dengan baik, khususnya anak usia 5-6 tahun. Hal yang harus dipahami oleh guru antara lain: (1) guru harus memahami terkait adanya ketergantungan pada diri anak, dimana hal ini menguntungkan bagi anak dalam melakukan kerjasama dalam bermain; (2) guru memahami bagaimana interaksi dua arah antara anak satu dan anak lainnya; (3) guru meyakinkan pada anak bagaimana mewujudkan sikap bertanggungjawab dalam melakukan sesuatu; (4) guru memahami bahwa setiap anak memiliki keterampilan interpersonal yang berbeda-beda (David, dkk, dikutip Suyanto, 2005). Hal tersebut juga mendapat dukungan dari hasil penelitian Zahro dan Nai'mah (2020) bahwa ketika anak-anak berada di dalam maupun di luar kelas, tidak ada anak-anak yang rebutan mainan, kursi, dan barangbarang lainnya.

Penciri kemapuan kerjasama anak usia diri juga dijelaskan oleh Morrison (2012) sebagai berikut: (1) adanya interaksi dua arah; (2) adanya sikap simpati pada diri anak; (3) adanya sikap mau berbagi deegan teman; (4) adanya sikap berdiskusi menyelesaikan konflik dengan teman; (5) adanya sikap sabar menunggu giliran dalam permainan; dan (6) anak saling menghargai dan menghormati antar teman. Selain itu, Erikson (2010) menjelaskan bahwa anak akan belajar lepas dari ketergantungan terhadap kedua orangtuanya, dan belajar menjalin interaksi dengan teman sebaya serta mengurangi egosentrisnya untuk dapat membaur bermain bekerjasama dengan kelompoknya.

Tujuan dari penelitian ini adalah untuk mengeksplorasi dan mendeskripsikan pembentukan kemampuan bekerjasama anak usia dini melalui permainan kreatif di TK Kusuma Mulia I Cerme Kabupaten Kediri.

\section{METODE PENELITIAN}

Jenis penelitian yang digunakan adalah penelitian kualitatif. Metode penelitian kualitatif digunakan untuk mengeksplorasi dan memahami makna yang oleh sejumlah individu atau sekelompok orang berasal dari 
Jurnal PG-PAUD Trunojoyo : Jurnal Pendidikan dan Pembelajaran Anak Usia Dini, Volume 7, Nomor 2, Oktober 2020 hal 44 - 51 , ISSN : 2528-3553 (online), ISSN: 2407-4454 (print)

masalah sosial atau kemanusiaan (Creswell, 2009). Pendekatan penelitian yang digunakan adalah deksriptif analitis yang berfungsi untuk meneliti kejadian yang berlangsung dan berhubungan dengan kondisi masa sekarang.

Proses pengumpulan dan penggalian data dalam penelitian ini, peneliti menggunakan beberapa metode, antara lain: observasi terhadap anak usia 5-6 tahun, wawancara kepada kepala sekolah dan guru, dan menggunakan studi dokumentasi, seperti RPPH, RPPM, catatan harian, dan penilaian anak yang didokumentasikan oleh guru kelas.

\section{HASIL DAN PEMBAHASAN}

Kemampuan bekerjasama dilakukan untuk kepentingan dan tujuan bersama (Saputra \& Rudyanto, 2005), yang dapat memunculkan hubungan timbal balik yang positif. Salah satu peran guru dalam membentuk dan mengembangkan sikap kerjasama pada anak adalah mengenalkan permainan yang bersifat kerjasama (Musfiroh, Seriati, \& Ayriza, 2007).

Seiring dengan berjalannya waktu, guru TK Kusuma Mulia I Cerme Kediri khususnya yang mengajar pada anak usia 5-6 tahun, mulai berbenah dan memunculkan ide untuk meningkatkan kerjasama anak dengan mengenalkan permainan yang melibatkan minimal 10 anak. Permainan tersebut dikenal dengan permainan pohon dan tupai. Ketika anak menyelesaikan tugas, setiap anak dalam masing-masing kelompok diwajibkan untuk berinteraksi dan bekerja sama, yang dapat mengurangi egosentrisme anak. Adanya permainan membuat kemampuan kerjasama TK Kusuma Mulia I Cerme mengalami kemajuan secara bertahap.

Media yang dibutuhkan dalam permainan pohon dan tupai antara lain: (1) topeng bergambar tupai; (2) daun nangka (sebagai mahkota pohon); dan (3) Tali raffia. Penerapan permainan kreatif pohon dan tupai ini antara lain: (1) Guru kelas membagi anak menjadi 2 kelompok. Kelompok pertama anak berperan menjadi pohon yaitu sejumlah 12 anak yang berpasangan dan terdiri dari 6 pohon. Kelompok kedua berperan menjadi tupai yang beranggotakan 7 anak, dan satu anak berperan menjadi pemandu permainan. Hal ini berarti ada 6 pohon, 7 tupai dan 1 pemandu.; (2) Guru membuat 6 lingkaran bahwa setiap lingkaran di isi dengan 2 anak yang menjadi pohon dan kedua tangan anak di angkat ke atas saling menempelkan kedua tangan tersebut. Kemudian guru membuat 1 lingkaran lagi yang agak besar untuk di tempati 7 anak yang menjadi tupai; (3) Seorang anak memberikan sebuah aba-aba "tupai yang mencari pohon" secara berulang, dan anak yang berperan menjadi tupai tersebut harus berlari mencari perlindungan di bawah anak yang berperan menjadi pohon. Setelah mendapatkan pohon tupai langsung berlindung dengan cara duduk di tengahtengah kedua anak yang menjadi pohon tersebut, dan bila ada 1 anak yang berperan menjadi tupai tersebut tidak mendapat bagian tempat di pohon, maka anak tersebut mendapatkan hukuman yaitu menyanyi sesuka hati lagu apa yang ingin di nyanyikan di tengah-tengah anak yang bermain; (4) Selanjutnya permainan di mulai lagi dengan seorang anak yang memberi aba-aba "pohon yang mencari tupai" secara berulang, maka anak yang berperan sebagai pohon harus berlari berebut untuk melindungi 1 tupai, dan bila ada 1 tupai yang tidak terlindungi maka akan mendapatkan hukuman yang sama; (5) Setelah beberapa kali permainan, seorang guru dapat menukarkan peran anak yang tadi menjadi tupai sekarang menjadi pohon; (6) Permainan ini bisa berakhir bila anak-anak sudah lelah, dan ingin mengakhiri permainan tersebut, anak boleh mengungkapkannya kepada guru.

Adanya kegiatan permainan pohon dan tupai yang sudah dikonsepkan oleh salah satu guru TK Kusuma Mulia I Cerme Kediri tersebut memiliki dampak tidak hanya pada aspek pengembangan sosial emosional saja, yaitu saat anak berperan menjadi pohon, maka 
Jurnal PG-PAUD Trunojoyo : Jurnal Pendidikan dan Pembelajaran Anak Usia Dini, Volume 7, Nomor 2, Oktober 2020 hal 44 - 51 , ISSN : 2528-3553 (online), ISSN: 2407-4454 (print)

anak harus bekerjasama untuk mencari tupai. Lebih lanjut, penerapan permainan kreatif pohon dan tupai ini memiliki dampak pada pengembangan nilai agama dan moral. Ketika anak melakukan permainan pohon dan tupai anak mampu bersikap toleransi dan menghargai terhadap teman yang mendapatkan hukuman bernyanyi. Ketika anak yang menjadi tupai tidak kebagian pohon, dan teman yang menjadi pohon tidak kebagian tupai, anak-anak mampu bersikap toleransi dengan menghargai temannya dan memberikan semangat.

Anak-anak juga mampu mengembangkan kemampuan berbahasanya yaitu dalam hal memahami dua instruksi atau lebih, yaitu ketika seorang anak memberi aba-aba "Pohon yang mencari tupai!" dan aba-aba "Tupai yang mencari pohon!". Anak harus mampu memahami instruksi guru dengan benar dan didukung oleh seorang pemandu yang dapat memberikan instruksi secara jelas dan tepat. Pernyataan guru di atas senada dengan kajian yang dilakukan oleh Nugroho (2013) bahwa permainan kreatif dapat mengembangkan semua aspek perkembangan pada anak, diantaranya aspek sosial emosional, kognitif, bahasa, dan fisik motorik.

Peran guru selanjutnya dalam hal membentuk kerjasama melalui permainan kreatif ini adalah melihat karakteristik bermain anak. Ketika guru mengamati memang anak terlihat bermain. Namun seorang guru, perlu mengenali karakteristik anak ketika bermain. Berdasarkan kajian Smith, dkk, (dikutip Tedjasaputra, 2001), guru perlu mengenali motivasi dari dalam diri anak untuk bermain; mengenali emosi positif yang dirasakan anak, seperti halnya: adanya kesenangan pada diri anak dimana anak merasakan begitu antusias dan bahagia saat bermain; memantau aktivitas anak dari satu aktivitas ke aktivitas lain; guru menilai dan menekankan pada proses bermain anak; dan guru harus memahami bahwa anak tidak merasakan tekanan ketika bermain.
Secara teoritis, permainan kreatif pohon dan tupai sesuai dengan teori yang dikembangkan oleh Parten (Ismail, 2006). Permainan ini dicirikan dengan adanya pembagian tugas dan peran pada anak yang terlibat di dalam permainan. Guru dapat berperan sebagai provokator, memberikan stimulus kepada anak agar dalam bermain memunculkan siapa yang memimpin permainan. Guru membagi tugas, menentukan anak siapa yang mau menjadi pemimpin, dan nanti bila ada anak yang bersedia menjadi pemimpin akan mendapatkan bintang (Kusumastuti, 2017). Hal ini juga sesuai dengan permainan pohon dan tupai dengan adanya peran pemandu dalam permainan tersebut, yang ditentukan langsung oleh guru.

Adanya minat bermain anak yang besar yang sudah dijelaskan oleh guru TK Kusuma Mulia I Cerme Kediri diharapkan dapat meningkatkan kemampuan kerjasama pada anak usia dini, terutama anak usia 5-6 tahun di TK Kusuma Mulia I Cerme Kediri. Hal ini berarti bahwa permainan kreatif pohon dan tupai, sangat efektif bagi pengembangan kemampuan kerjasama anak. Selain itu, pelaksanaan kegiatan yang selama ini melalui kegiatan bercerita dan tanya jawab, maka dengan adanya permainan kreatif pohon dan tupai anak dapat terlibat aktif dan mempraktekkan secara langsung ketika bermain di dalam kelompok yang membutuhkan kerjasama. Hasil observasi dan wawancara ini mendukung hasil penelitian Kusumastuti (2017) bahwa kemampuan kerjasama anak usia 5-6 tahun dapat ditingkatkan melalui permainan yang sifatnya konstruktif, dan permainan konstruktif merupakan bagian dari permainan kerjasama. Begitu juga, didukung oleh hasil penelitian Hidayati (2014) bahwa bermain permainan tradisional mempengaruhi peningkatan kemampuan kerjasama anak, dan bila seorang guru ingin mengembangkan permainan kreatif maka diperlukan kreatifitas dari seorang guru dalam mencipta bahkan memodifikasi 
Jurnal PG-PAUD Trunojoyo : Jurnal Pendidikan dan Pembelajaran Anak Usia Dini, Volume 7, Nomor 2, Oktober 2020 hal 44 - 51 , ISSN : 2528-3553 (online), ISSN: 2407-4454 (print)

permainan tradisional agar semakin bervariasi (Nugraha, 2013)

\section{SIMPULAN DAN SARAN}

Pembentukan sikap kerjasama dapat dilakukan melalui salah satu permainan kreatif yaitu permainan pohon dan tupai, dimana permainan dilakukan dengan adanya kerjasama yang diwujudkan dengan pembagian tugas serta peran saat anak terlibat di dalam permainan. Hal ini berarti bahwa permainan kreatif pohon dan tupai, tepat digunakan untuk mengembangkan kemampuan kerjasama anak. Guru sebagai fasilitator dan provokator positif memberikan perhatian kepada anak supaya mau menjadi pemimpin di dalam kelompok, sehingga anak mampu bekerjasama dan anak dapat bermain dengan lancar.

Bagi Guru, bahwa guru perlu memperluas pemahaman dan mencari pengetahuan secara mendalam dan sebanyakbanyaknya tentang beraneka ragam permainan kreatif, baik hasil dari modifikasi permainan tradisional, maupun permainan yang dibuat sesuai dengan karakteritik pembelajaran taman kanak-kanak. Adapun hal itu dilakukan bertujuan menjadikan kegiatan pembelajaran anak sesuai dengan prinsip bermain sambil belajar, belajar seraya bermain.

Bagi peneliti selanjutnya, supaya memperluas dan mengkaji indikator-indikator sikap kerjasama anak usia dini dengan menggunakan penelitian kuantitatif, atau dengan menggunakan penelitian tindakan kelas

\section{DAFTAR PUSTAKA}

Creswell, J.W. (2009). Research design qualitative, quantitative, and mixed methods approaches. Third edition. Terjemahan oleh Achmad Fawaid, 2010. Yogyakarta: Pustaka Pelajar

Depdiknas. (2009). Permendiknas No. 58 Tahun 2009. Jakarta: Direktorat Jenderal Manajemen Pendidikan Dasar dan Menengah Direktorat Pembinaan TK SD, Depdiknas.

Depdiknas. (2013). Undang-Undang RI Nomor 20, Tahun 2003, tentang Sistem Pendidikan Nasional. Jakarta: Departemen Pendidikan Nasional.

Erikson, E. (2010). Childhood and society. Terjemahan oleh, Helly P. Soetjipto \& Sri Mulyantini Soetjipto, 2010. Yogyakarta: Pustaka Pelajar.

Fauziddin, M. (2016). Peningkatan kemampuan kerja sama melalui kegiatan kerja kelompok pada anak kelompok A TK Kartika Salo Kabupaten Kampar. Jurnal Obsesi: Jurnal Pendidikan Anak Usia Dini, 2(1), 29-45. https://doi.org/10.31004/obsesi.v2i1.4 7

Hidayati, W. (2014). Upaya Meningkatkan Kemampuan Kerjasama melalui Permainan Tradisional pada Anak Kelompok A Tk Aba Ledok I Kulon Progo Tahun Ajaran 2013/2014. Skripsi ini tidak di terbitkan. Yogyakarta: Fakultas Ilmu Pendidikan Universitas Negeri Yogyakarta.

Ismail, A. (2006). Education games: menjadi cerdas dan ceria dengan permainan edukatif. Yogyakarta: Pilar Media.

Kusumastuti, A.D. (2017). Peningkatan Kemampuan Kerjasama melalui Permainan Konstruktif pada Anak Kelompok B Di Tk Aba Plosokerep Bunder Patuk Gunung Kidul. Skripsi ini tidak di terbitkan. Yogyakarta: Fakultas Ilmu Pendidikan Universitas Negeri Yogyakarta.

Morrison, G.S. (2012). Dasar-dasar pendidikan anak usia dini. Terjemahan oleh Suci Romadhona dan Apri Widiastuti, 2012. Jakarta: PT. Indeks.

Mulyani, N. (2016). Super asyik permainan tradisional anak Indonesia. Yogyakarta: Diva Press. 
Jurnal PG-PAUD Trunojoyo : Jurnal Pendidikan dan Pembelajaran Anak Usia Dini, Volume 7, Nomor 2, Oktober 2020 hal 44 - 51 , ISSN : 2528-3553 (online), ISSN: 2407-4454 (print)

Musfiroh, T., Seriati, N.N., \& Ayriza, Y. (2007). Afiliasi resolusi konflik. Yogyakarta: Tiara Wacana.

Mutiah, D. (2010). Psikologi bermain anak usia dini. Jakarta: Kencana Prenada Media Group

Nugraha, B. (2013). Permainan kreatif untuk anak usia dini. Jurnal Pendidikan Anak, 2(1), 203-210. https://doi.org/10.21831/jpa.v2i1.3030

Safaria, T. (2005). Metode pengembangan kecerdasan interpersonal. Yogyakarta: Amara books.

Saputra, Y.M. \& Rudyanto. (2005). Pembelajaran kooperatif untuk meningkatkan keterampilan anak. Jakarta: Departemen Pendidikan Nasional, Direktorat Jenderal Pendidikan Tinggi, Direktorat Pendidikan Tenaga Kependidikan dan Ketenagaan Perguruan Tinggi.

Suyanto, S. (2005). Dasar-dasar pendidikan anak usia dini. Yogyakarta: Hikayat Publishing.

Tedjasaputra, M. S. 2001. Bermain, Mainan dan Permainan. Jakarta: PT. Grasindo.

Tusyana, E., Trengginas, R., \& Suyadi, S. (2019). Analisis perkembangan sosial emosional tercapai siswa usia dasar. Jurnal Inventa, 3(1), 18-26. https://doi.org/10.36456/inventa.3.1.a1 804

Zahro, S \& Nai'mah. (2020). Peran lingkungan sosial terhadap pembentukan karakter anak usia dini di jogja green school. Jurnal PG-PAUD Trunojoyo: Jurnal Pendidikan dan Pembelajaran Anak Usia Dini, 7(1), 1-9. https://doi.org/10.21107/pgpaudtrunojoy o.v7i1.6293. 